\title{
OCCURRENCE OF POLYCYCLIC AROMATIC HYDROCARBONS IN HUMAN DIET - EXPOSURE AND RISK ASSESSMENT TO CONSUMER HEALTH*
}

\author{
Andrzej Starski ${ }^{1}$, Anna Kukielska ${ }^{1}$, Jacek Postupolski ${ }^{1}$
}

${ }^{1}$ National Institute of Public Health NIH - National Research Institute, Warsaw, Poland

\begin{abstract}
Background. Polycyclic aromatic hydrocarbons (PAHs) are environmental pollutants, they are also present in food, in which their presence results from environmental pollution and food processing processes. Many compounds from this group, such as benzo(a)pyrene show important toxicity, including genotoxic carcinogenicity. In food heavier PAHs significantly toxic are observed.

Objective. The aim of the study was assessment of consumers exposure to PAHs from the diet of surveyed respondents. The assessment of contaminants content in daily food rations is characterized by less uncertainty factor than the assessment based on data on the contamination of individual foodstuffs and their consumption by humans.

Material and methods. Research material consisted of daily diets obtained from respondents participating in the study. Content of 22 PAHs (fluorene, phenanthrene, anthracene, fluoranthene, pyrene, benzo(c)fluorene, benz(a)anthracene, chrysene, 5-methylchrysene, perylene, benzo(b)fluoranthene, benzo(k)fluoranthene, benzo(j)fluoranthene, benzo(e) pyrene, benzo(a)pyrene, benzo(ghi)perylene, indeno(1,2,3-cd)pyrene, dibenzo(a,h)anthracene, dibenzo(a,e)pyrene, dibenzo(a,l)pyrene, dibenzo(a,h)pyrene, dibenzo(a,i)pyrene) in each of diets was tested using liquid chromatography with a fluorescence detector. The samples were purified by saponification, size exclusion chromatography (SEC) and solid phase extraction (SPE).

Results. 52 respondents $(\mathrm{n}=52)$ took part in the study. The highest median of PAHs were found for pyrene $(1.412 \mu \mathrm{g} /$ $\mathrm{kg})$, phenantrene $(1.276 \mu \mathrm{g} / \mathrm{kg})$, fluorene $(1.151 \mu \mathrm{g} / \mathrm{kg})$ and fluoranthene $(1.087 \mu \mathrm{g} / \mathrm{kg})$, they were about $10-80 \mathrm{higher}$ than the levels of heavier PAHs. In group of heavy PAHs quantitatively prevailed benzo(e)pyrene $(0.109 \mu \mathrm{g} / \mathrm{kg})$, benzo(b) fluroanthene $(0.070 \mu \mathrm{g} / \mathrm{kg})$, benzo(ghi)perylene $(0.065 \mu \mathrm{g} / \mathrm{kg})$ and perylene $(0.059 \mu \mathrm{g} / \mathrm{kg})$. Generally the median level of contamination with light PAHs was $6.045 \mu \mathrm{g} / \mathrm{kg}$, while with heavy ones $0.504 \mu \mathrm{g} / \mathrm{kg}$, in the case of the sum of 4 PAHs regulated in EU law content was $0.301 \mu \mathrm{g} / \mathrm{kg}$. In the tested samples average $24 \%$ of the PAH content was pyrene, light PAHs with a lower toxicity potential accounted for $92 \%$ of the content of tested compounds. Sum of 4 regulated PAHs accounted for $58 \%$ of content compounds selected by the EU as significant for the assessment of food contamination by PAHs. The composition of the participants' diets was analyzed in terms of determining factors influencing on high levels of PAHs. They were high fat level and presence of smoked or grilled meat and fish products. The mean exposure to benzo(a)pyrene was $0.52 \mathrm{ng} / \mathrm{kg}$ b.w. per day, while for the sum of 4 PAHs $3.29 \mathrm{ng} / \mathrm{kg}$ b.w. per day. For light PAHs high exposure was $90.6 \mathrm{ng} / \mathrm{kg}$ b.w. per day, while for heavy PAH it was $10.7 \mathrm{ng} / \mathrm{kg}$ b.w. per day. Risk assessment was performed by calculating the value of margin of exposure (MoE), which for benzo(a)pyrene and for sum of 4 PAHs were above 25,000 in both considered: mean and high exposure scenario.

Conclusions. Studied diets were a source of exposure to PAHs. Higher levels have been reported for light, less toxic PAH as compared to heavy PAH. In both considered scenarios margin of exposure were $>25000$. In case of studied diets no risk for consumer was found.
\end{abstract}

Key words: Polycyclic aromatic hydrocarbons, PAHs, benzo(a)pyrene, exposure, margin of exposure, total diet study

\section{STRESZCZENIE}

Wprowadzenie. Wielopierścieniowe węglowodory aromatyczne (WWA) stanowią zanieczyszczenie środowiskowe, występują również w żywności, w której ich obecność wynika zzanieczyszczenia środowiska oraz procesów przetwarzania żywności. Wiele związków z tej grupy wykazuje działalnie toksyczne w tym genotoksyczne kancerogenne, jak np. benzo(a)piren. W żywności obserwuje się cięższe WWA o większym potencjale toksycznym.

*) The work was carried out as part of the research project No. 2011/01/N/NZ7/06227 entitled 'Human health exposure assessment based on the analysis of exposure biomarkers related to the intake of carcinogenic polycyclic aromatic hydrocarbons (PAHs) in the diet' financed by the National Science Center in Poland.

Corresponding author: Andrzej Starski, National Institute of Public Health NIH - National Research Institute, Department of Food Safety, Chocimska 24 Str., 00-791 Warsaw, Poland, tel. no. +48 22542 1383, e-mail: astarski@pzh.gov.pl

(C) Copyright by the National Institute of Public Health NIH - National Research Institute 
Cel. Celem pracy była ocena narażenia konsumentów na WWA pochodzące z diety badanych respondentów. Ocena zawartości zanieczyszczeń w całodziennych racjach pokarmowych cechuje się mniejszą niepewności niż ocena na podstawie danych o zanieczyszczeniu poszczególnych środków spożywczych i ich spożyciu przez ludzi.

Material i metody. Materiał badawczy stanowiły całodzienne diety uzyskane od respondentów biorących udział w badaniu. W każdej z diet badano zawartość 22 WWA (fluoren, fenantren, antracen, fluoranten, piren, benzo(c)fluoren, benz(a)antracen, chryzen, 5-metylochryzen, perylen, benzo(b)fluoranten, benzo(k)fluoranten, benzo(j)fluoranten, benzo(e)piren, benzo(a)piren, benzo(ghi)perylen, indeno(1,2,3-cd)piren, dibenzo(a,h)antracen, dibenzo(a,e)piren, dibenzo(a,l)piren, dibenzo(a,h)piren, dibenzo(a,i)piren), zastosowano technikę chromatografii cieczowej z detektorem fluorescencyjnym. Próbki oczyszczano metodą zmydlania, a następnie techniką chromatografii wykluczenia (SEC) i ekstrakcji do fazy stałej (SPE).

Wyniki. W badaniu udział wzięło 52 respondentów $(\mathrm{n}=52)$. Najwyższe wartości mediany występowania WWA w diecie stwierdzono dla pirenu $(1,412 \mu \mathrm{g} / \mathrm{kg})$, fenantrenu $(1,276 \mu \mathrm{g} / \mathrm{kg})$, fluorenu $(1,151 \mu \mathrm{g} / \mathrm{kg})$ i fluorantenu $(1,087 \mu \mathrm{g} / \mathrm{kg})$, były one około 10-80 wyższe niż poziomy zawartości cięższych WWA. W grupie cięższych węglowodorów ilościowo przeważał benzo(e)piren $(0,109 \mu \mathrm{g} / \mathrm{kg})$, benzo(b)fluroanten $(0,070 \mu \mathrm{g} / \mathrm{kg})$, benzo(ghi)perylene $(0,065 \mu \mathrm{g} / \mathrm{kg})$ orazperylen $(0,059 \mu \mathrm{g} / \mathrm{kg})$. Ogółem poziom mediany zanieczyszczenia lekkimi WWA wynosił $6,045 \mu \mathrm{g} / \mathrm{kg}$, natomiast ciężkimi $0,504 \mu \mathrm{g} / \mathrm{kg}$, w przypadku sumy 4 WWA uregulowanych w przepisach UE zawartość wynosiła $0,301 \mu \mathrm{g} / \mathrm{kg}$. W badanych próbkach przeciętnie 24\% zawartości WWA stanowił piren, ogółem lekkie WWA o mniejszym potencjale toksycznym stanowiły 92\% zawartości badanych związków. Suma 4 uregulowanych WWA stanowiła 58\% zawartości wytypowanych przez UE jako istotne dla oceny zanieczyszczenia żywności. Przeanalizowano skład diet uczestników pod kątem określenia czynników wpływających na wysokie poziomy WWA. Były to wysoka zawartość tłuszczu oraz obecność produktów mięsnych i rybnych wędzonych lub grillowanych. Średnie narażenie na benzo(a)piren wynosiło 0,52 ng/kg m.c./dzień, natomiast na sumę 4 WWA 3,29 ng/kg m.c./dzień. Dla lekkich WWA wysokie narażenie wynosiło 90,6 ng/kg m.c./dzień, natomiast da ciężkich WWA 10,7 ng/kg m.c./dzień. Oceny ryzyka dokonano obliczając wartość marginesu narażenia, który zarówno dla benzo(a)pirenu jak i sumy 4 WWA wynosił powyżej 25000 dla obu badanych scenariuszy narażenia (średniego i wysokiego).

Wnioski. Badane diety stanowiły źródło narażenia na WWA. Wyższe poziomy odnotowano dla lekkich mniej toksycznych WWA w porównaniu z ciężkimi WWA. W przypadku badanych diet nie stwierdzono ryzyka dla zdrowia konsumentów.

Słowa kluczowe: wielopierścieniowe węglowodory aromatyczne, WWA, benzo(a)piren, narażenie, margines narażenia, badanie całodziennej diety

\section{INTRODUCTION}

Polycyclic aromatic hydrocarbons (PAHs) are a large group of hydrocarbons composed of at least 2 aromatic rings. These substances are formed in combustion processes and constitute environmental pollution, they are present in water [28], air [27], also are a factors of exposure at certain workplaces [13, 21] and are contained in tobacco smoke [1]. They are also present in food [7, 5, 11, 22]. Higher levels of PAHs are observed in high food with high content of fat, e.g. oils and fats, meat and fish products. These compounds are present also food stuffs subjected to heat (e.g. grilling) or smoke treatment. They show various toxic effects, some light PAHs, e.g. pyrene, are classified as compounds with a low toxic potential, even 1000 times lower than the well-known heavy PAH benzo $(a)$ pyrene, which is a carcinogenic factor for humans $[22,10]$. The reported value of 1000 results from the use of the toxic equivalent factor (TEF), which assign value of 1 for benzo(a)pyrene. For pyrene, fluorene, fluoranthene and phenanthrene these values are lower and equal 0.001 , for chrysene 0.01 , for benz(a) anthracene and benzo(b)fluoranthene 0.1 [17].

PAHs show little chemical reactivity. In the human body, in the first phase of metabolism, they undergo oxidation on the CYP450 cytochrome to hydroxy- and polyhydroxy hydrocarbons: diols, triols and tetraols.
In this process also epoxides can be formed, which characterized by high reactivity and affinity to purine bases [22]. The covalent bond between the epoxide and the DNA base leads to damage (mutation) of the strand, which may cause carcinogenesis. Therefore benzo $(a)$ pyrene is classified as a genotoxic carcinogen $[22,15,18]$. The International Agency for Research on Cancer (IARC) classifies this compound in the group of agents with proven carcinogenic effect on humans, i.e. group I [10]. Studies linking toxicity with the structure of the PAH molecule have shown that heavier PAHs are particularly toxic and can create a characteristic spatial structure called 'bay-region'. Epoxides of these compounds show a significant genotoxic and carcinogenic effect [16].

Considering a human exposure it is important to emphasized that PAHs are a group of compounds for which numerous and diverse sources of exposure should be taken into account $[10,20]$. In the case of environmental exposure relatively high levels of light PAHs (3-4 ring compounds) are observed in comparison to heavier PAHs with 5 and more rings [22]. For food this difference is less significant due to the both lower levels of light PAHs and higher levels of heavier, more toxic PAHs. These substances are non-volatile, their presence in the environment is related to pollution by dust, especially PM1, PM2.5 and PM10 fractions [27] to which heavier PAHs 
show high adhesion. Food contamination by PAHs is favoured by very good fat solubility. Therefore it should be emphasized that from the point of view of risk to human health, food is a particularly important source of exposure. The risk related to the presence of PAHs in food and human environment should be considered taking into account many compounds, two most studied groups are called 16 PAHs according to EPA [29], as well as 15 PAHs according to EU recommendation, usually supplemented with benzo(c) fluorene $[11,3]$. The PAHs group established by the EPA is universal, these compounds occur both in food and in environment. PAHs from the 16th EU are characteristic of oral exposure.

Over the last few decades many studies have been written on the presence of PAH in food. One of the more comprehensive studies are published by European Food Safety Authority (EFSA) [7, 5] and the former Scientific Committee on Food [22]. The most common approach to exposure assessment is to determine the content of individual PAHs in different foodstuffs. Taking into account available data on the consumption of individual foodstuffs and level of contamination it is possible on this basis to calculate the product of these values which represent exposure of consumers. It is possible to adopt different exposure scenarios with lower and higher levels of contamination or consumption. However this approach is burdened relatively high uncertainty, because in relation to the level of contamination, uncertainty regarding consumption of foodstuffs is much greater. This approach is used in numerous works, including the mentioned EFSA studies.

Another approach which reduce uncertainty related to consumption is the total diet study approach (TDS) [9]. TDS are used to determine the content of many toxic substances including PAHs and various food constituents in reliable diets consumed by consumers. Such diets are much more representative for reliable consumption than calculation based on addition consumption of each foodstuffs. This approach also takes into account increase (or decrease) level of contamination resulting from culinary processing performed by consumers. Determining exposure and then risk to consumer health from TDS studies is more reliable than calculations based on consumption. However a significant limitation of the TDS approach is the much lower availability of consumers' daily diets, mainly related to the difficulty in obtaining appropriate samples. The objective of this study was to assess the exposure and risk to human health related to PAHs presence in diets of consumers, who took part in the study. They prepared samples for testing in line with the rule: "prepare an identical meal for yourself and study organizer". Obtained results were also compared with other similar studies.

\section{MATERIAL AND METHODS}

\section{Diets}

Diets were accumulated in summer 2015 from 52 study participants. Each participants lived in Warsaw. Each person accumulated a meal from one day. Study participants were asked to prepare meals identically and in identical amounts for themselves and for the purposes of the diet study. All persons were instructed in the preparation of diet samples and their storage. Participants of the study kept 'Test diary' in which they recorded in detail information on food preparation, ingredients used, cooking method and the time of consumption of each meal. Individual meals were packed in separate containers (provided by the test organizer) so that their contents could be verified against information in the diary. Participants reported also the year of birth, sex and body weight on the day of taking the diet.

\section{Handling of samples}

The test samples provided by the participants after checking the compliance with the study diary were weighed and then frozen $\left(-18^{\circ} \mathrm{C} \div-24^{\circ} \mathrm{C}\right)$ until the PAH determinations were made. For the homogenization samples from one participant were combined into 2-4 bulk samples according to the type of food, in particular fat or water content and consistency (high fat and low fat samples were homogenized separately). Homogenization was performed using an UltraTurrax homogenizer until a homogeneous mass was achieved. Before homogenization samples with a high fat content were heated in a water bath at $40^{\circ} \mathrm{C}$. The composite samples were weighed and a aliquot portion was taken from each of them to form one laboratory sample representing the participant's entire diet. The weight of the laboratory sample was approximately $50 \mathrm{~g}$.

\section{Reagents and standards}

The following reagents were used: ethyl alcohol 96\% p.a. (POCh), cyclohexane p.a. (Chempur), ethyl acetate p.a. (Chempur), hexane p.a. (Sigma), dichloromethane p.a. (Baker UltreResi), HPLC acetonitrile (Baker HPLC gradient grade), sodium hydroxide p.a. (Chempur), acetic acid glacial p.a. (Sigma), sodium sulphate anhydrous p.a. (Sigma). Deionized water of HPLC purity was used. BioBeads SX-3 (BioRad) gel was used to purify the sample on a size exclusion chromatography (SEC) column. For solid phase extraction (SPE) purification, $1 \mathrm{~g}, 6 \mathrm{ml}$ silicagel columns (JT Baker) were used. Following standards were purchased: PAH-Mix 45 from Dr Ehrenstorfer GmbH containing naphthalene, acenafthene, acenaphthylene, fluorene, phenanthrene, anthracene, fluoranthene, pyrene, benz( $a$ anthracene, chrysene, perylene, benzo(b)fluoranthene, benzo $(k)$ 
fluoranthene, benzo(e)pyrene, benzo(a)pyrene, benzo $(g h i)$ perylene, indeno( $(1,2,3-c d)$ pyrene and dibenzo $(a, h)$ anthracene each $10 \mathrm{ng} / \mu \mathrm{l}$ in cyclohexane and PAH-Mix 183 from Dr Ehrenstorfer $\mathrm{GmbH}$ containing benzo $(c)$ fluorine, $\operatorname{benz}(a)$ anthracene, chrysene, 5-methylchrysene, benzo(b)fluoranthene, benzo $(k)$ fluoranthene, benzo $(j)$ fluoranthene, $\operatorname{benzo}(a)$ pyrene, benzo $(g h i)$ perylene, cyclopenta $(c d)$ pyrene, indeno $(1,2,3-c d)$ pyrene, dibenzo $(a, h)$ anthracene, dibenzo $(a, e)$ pyrene, dibenzo $(a, l)$ pyrene, dibenzo $(a, h)$ pyrene and dibenzo $(a, i)$ pyrene each $10 \mathrm{ng} / \mu \mathrm{l}$ in cyclohexane.

\section{Sample preparation}

$10 \mathrm{~g}$ of homogeneous laboratory sample was weighed. Sample was placed in a round bottom flask and then $100 \mathrm{ml}$ of a solution of $1.5 \mathrm{M}$ sodium hydroxide in ethanol was added. The flask fitted with a reflux condenser was heated in a heating bowl to the solution boiling temperature for 2 hours. Then contents of the flask were diluted with $100 \mathrm{ml}$ of $10 \%$ acetic acid solution with water and whole mixture was transferred to the separatory funnel. It was extracted with two $50 \mathrm{ml}$ portions of cyclohexane and dried over anhydrous sodium sulfate. The cyclohexane solution was concentrated on rotary evaporator in a water bath at $40^{\circ} \mathrm{C}$ to a volume of about $5 \mathrm{ml}$. The resulting concentrated extract was dispensed onto a size exclusion chromatography (SEC) column. Working parameters of the SEC/GPC chromatograph: filling Bio-Beads SX3 gel (in-house packed), sample was dissolved in SEC/GPC solvent cyclohexane:ethyl acetate $=1: 1(\mathrm{v} / \mathrm{v})$ and filled up to $10 \mathrm{ml}, 7 \mathrm{ml}$ was injected to loop, initial flow $1 \mathrm{ml} / \mathrm{min}$ (during loop washing), then was increased to $2 \mathrm{ml} / \mathrm{min}$. First fraction of $40 \mathrm{ml}$ was discarded and second fraction (proper) of $35 \mathrm{ml}$ was collected. Obtained fraction was concentrated by rotary evaporator in water bath at $40^{\circ} \mathrm{C}$. The residue was reconstituted in $1 \mathrm{ml}$ of hexane:dichloromethane $=3: 1(\mathrm{v} / \mathrm{v})$ and applied to previously conditioned SPE column containing $1 \mathrm{~g}$ of silicagel, then elute with $8 \mathrm{ml}$ of hexane/dichloromethane (as above). The resulting fraction was concentrated at $40^{\circ} \mathrm{C}$ under a gentle stream of nitrogen. The residue was reconstituted in 1 $\mathrm{ml}$ of acetonitrile.

\section{Determination of PAH content}

Standard laboratory equipment and laboratory glassware were used. SEC/GPC purification was performed using a $500 \mathrm{~mm}$ x $15 \mathrm{~mm}$ (internal diameter) Omnifit glass column (Sigma) and Waters 501 chromatographic pump equipped with the injection valve with a loop of $8 \mathrm{ml}$, fraction collector valve and electronic controller (of our own design). For separation and measure PAHs content high performance liquid chromatograph was used. HPLC
Waters Alliance 2695 was equipped with column Agilent PAH Pursuit $250 \mathrm{~mm} \times 4.6 \mathrm{~mm}$ column, 5 $\mu \mathrm{m}$, integrated with a $10 \mathrm{~mm} \times 4.6$ guard column as well as equipped with column oven, automatic sample dispenser equipped and Waters 2475 fluorescence detector.

The determination was performed using a highperformance liquid chromatograph equipped with a column dedicated to the determination of PAHs and a fluorescence detector. A sample volume of $50 \mu \mathrm{l}$ was injected. Temperature of chromatographic column was set at $30^{\circ} \mathrm{C}$. Gradient elution program: solvent A: acetonitrile, solvent $\mathrm{B}$ : water; flow $1 \mathrm{ml} / \mathrm{min}$; A: $0 \mathrm{~min}$ $50 \%$ (vol.), $20 \mathrm{~min} 50 \%$, $50 \mathrm{~min} 90 \%, 75 \mathrm{~min} 90 \%$, $80 \mathrm{~min} 100 \%$ to $110 \mathrm{~min}$. Frequency of excitation (ex) and emission (em) for individual compounds for fluorescence detector (ex $[\mathrm{nm}] / \mathrm{em}[\mathrm{nm}])$ and retention times [min]: FLN 270/323 $\mathrm{R}_{\mathrm{t}}=29,3$; PHE $252 / 370 \mathrm{R}_{\mathrm{t}}=32,6$; ANT 252/402 $\mathrm{R}_{\mathrm{t}}=35,5$; FLT 280/460 $\mathrm{R}_{\mathrm{t}}=38,6$; PYR 270/375 $\mathrm{R}_{\mathrm{t}}=40,5 ; \mathrm{BcFl} 309 / 357 \mathrm{R}_{\mathrm{t}}=41,1$; BaA 286/387 $\mathrm{R}_{\mathrm{t}}=46,9$; CHR 266/408 $\mathrm{R}_{\mathrm{t}}=48,0 ; 5 \mathrm{MCh}$ 266/382 $\mathrm{R}_{\mathrm{t}}=49,8$; BeP 286/387 $\mathrm{R}_{\mathrm{t}}=52,0$; BjF 250/510 $\mathrm{R}_{\mathrm{t}}=51,6$; BbF 298/433 $\mathrm{R}_{\mathrm{t}}=52,7$; PER 406/439 $\mathrm{R}_{\mathrm{t}}=52,8$; BkF 298/433 $\mathrm{R}_{\mathrm{t}}=54,7$; BaP 380/406 $\mathrm{R}_{\mathrm{t}}=56,9$; DBahA 286/397 $\mathrm{R}_{\mathrm{t}}=61,1 ;$ DBalP 313/446 $\mathrm{R}_{\mathrm{t}}=61,4 ;$ BghiP 286/408 $\mathrm{R}_{\mathrm{t}}=64,2$; IcdP 300/502 $\mathrm{R}_{\mathrm{t}}=66,3$; DBaeP 386/397 $\mathrm{R}_{\mathrm{t}}=71,6$; DBaiP 292/434 $\mathrm{R}_{\mathrm{t}}=96,0$; DBahP $307 / 451 R_{t}=105,3$. Each sample was injected twice. Calibration covers 6 points injected twice.

\section{Validation parameters}

Determination of PAHs in total diets was performed with in-house validated method. Laboratory is covered by a quality management system compliant with the PN-EN ISO/IEC 17025:2018. Table 1 presents the most important validation parameters for individual compounds, such as limit of detection (LOD), limit of quantification (LOQ), recovery, repeatability, working range, slope of the calibration curve and expanded measurement uncertainty. Validation experiment based on testing 6 samples at each of the three validation levels.

\section{RESULTS AND DISCUSSION}

In case of polycyclic aromatic hydrocarbons it is important to analyze the presence of specific groups of compounds, which is distinguished taking into account number of rings, toxicity and source of exposure. One of the most frequently used distinction is division into light PAHs, which include among other 3 and 4 rings and heavy, which include 5 and 6 rings compounds. Light hydrocarbons are observed at higher concentration levels in food and are also present in air and water. For heavier compounds, lower levels are recorded. The heaviest dibenzopyrenes are 
Table 1. Validation parameters for the method of determination of polycyclic aromatic hydrocarbons in diets. Abbreviations used in the text are also listed

\begin{tabular}{|c|c|c|c|c|c|c|c|c|}
\hline \multirow[t]{2}{*}{ PAH } & \multirow[t]{2}{*}{$\begin{array}{l}\text { Abbre- } \\
\text { viation }\end{array}$} & LOD & LOQ & Recovery & $\begin{array}{l}\text { Repeat- } \\
\text { ability } \\
\operatorname{RSD}_{\mathrm{r}}\end{array}$ & $\begin{array}{c}\text { Expanded } \\
\text { uncer- } \\
\text { tainty } \\
\mathrm{U}_{c}\end{array}$ & $\begin{array}{l}\text { Working } \\
\text { range }\end{array}$ & $\begin{array}{c}\text { Slope } \\
\text { of cali- } \\
\text { bration } \\
\text { curve }\end{array}$ \\
\hline & & $\mu \mathrm{g} / \mathrm{kg}$ & $\mu \mathrm{g} / \mathrm{kg}$ & $\%$ & $\%$ & $\mu \mathrm{g} / \mathrm{kg}$ & $\mu \mathrm{g} / \mathrm{kg}$ & \\
\hline fluorene & FLN & 0.030 & 0.050 & 84.2 & 11.7 & 18.0 & $0.05-5.00$ & $7.02 \cdot 10^{6}$ \\
\hline phenanthrene & PHE & 0.050 & 0.100 & 93.1 & 12.5 & 20.1 & $0.10-5.00$ & $2.23 \cdot 10^{6}$ \\
\hline anthracene & ANT & 0.030 & 0.050 & 96.1 & 12.2 & 19.0 & 0.05-5.00 & $7.15 \cdot 10^{6}$ \\
\hline fluoranthene & FLT & 0.030 & 0.050 & 89.0 & 13.0 & 21.1 & $0.05-5.00$ & $1.32 \cdot 10^{6}$ \\
\hline pyrene & PYR & 0.050 & 0.100 & 98.0 & 6.6 & 12.8 & $0.10-10.00$ & $3.51 \cdot 10^{6}$ \\
\hline benzo $(c)$ fluorene & $\mathrm{BcFl}$ & 0.020 & 0.040 & 98.5 & 6.4 & 11.3 & $0.04-5.00$ & $9.65 \cdot 10^{6}$ \\
\hline benz $(a)$ anthracene & $\mathrm{BaA}$ & 0.010 & 0.020 & 99.1 & 6.3 & 11.0 & $0.02-5.00$ & $7.71 \cdot 10^{6}$ \\
\hline chrysene & CHR & 0.020 & 0.040 & 101.2 & 6.5 & 11.4 & $0.04-5.00$ & $5.51 \cdot 10^{6}$ \\
\hline 5-methylchrysene & $5 \mathrm{MCh}$ & 0.010 & 0.020 & 94.8 & 8.9 & 15.1 & $0.02-5.00$ & $4.04 \cdot 10^{6}$ \\
\hline perylene & PER & 0.020 & 0.040 & 74.1 & 13.2 & 18.8 & $0.04-5.00$ & $1.83 \cdot 10^{7}$ \\
\hline benzo(b)fluoranthene & $\mathrm{BbF}$ & 0.010 & 0.020 & 91.2 & 8.3 & 14.5 & $0.02-5.00$ & $3.04 \cdot 10^{6}$ \\
\hline benzo $(k)$ fluoranthene & $\mathrm{BkF}$ & 0.004 & 0.005 & 89.4 & 8.1 & 14.0 & $0.005-5.00$ & $1.58 \cdot 10^{7}$ \\
\hline benzo $(j)$ fluoranthene & $\mathrm{BjF}$ & 0.060 & 0.120 & 103.7 & 9.1 & 15.0 & $0.12-5.00$ & $6.49 \cdot 10^{4}$ \\
\hline benzo(e)pyrene & $\mathrm{BeP}$ & 0.010 & 0.020 & 90.3 & 8.9 & 14.6 & $0.02-5.00$ & $1.67 \cdot 10^{6}$ \\
\hline benzo $(a)$ pyrene & $\mathrm{BaP}$ & 0.005 & 0.010 & 83.8 & 9.4 & 16.1 & 0.01-5.00 & $4.45 \cdot 10^{6}$ \\
\hline benzo(ghi)perylene & BghiP & 0.010 & 0.020 & 70.9 & 12.6 & 21.3 & $0.02-5.00$ & $2.78 \cdot 10^{6}$ \\
\hline indeno $(1,2,3-c d)$ pyrene & IcdP & 0.010 & 0.020 & 83.4 & 11.0 & 17.7 & $0.02-5.00$ & $7.09 \cdot 10^{5}$ \\
\hline dibenzo $(a, h)$ anthracene & DBahA & 0.020 & 0.040 & 91.6 & 9.1 & 14.9 & $0.04-5.00$ & $5.33 \cdot 10^{6}$ \\
\hline dibenzo $(a, e)$ pyrene & DBaeP & 0.020 & 0.040 & 71.7 & 16.8 & 27.0 & $0.04-5.00$ & $4.36 \cdot 10^{6}$ \\
\hline dibenzo $(a, l)$ pyrene & DBalP & 0.020 & 0.040 & 68.6 & 17.2 & 28.0 & $0.04-5.00$ & $3.94 \cdot 10^{6}$ \\
\hline dibenzo $(a, h)$ pyrene & DBahP & 0.020 & 0.040 & 79.4 & 15.0 & 24.8 & $0.04-5.00$ & $3.47 \cdot 10^{7}$ \\
\hline dibenzo $(a, i)$ pyrene & DBaiP & 0.020 & 0.040 & 55.9 & 17.6 & 36.5 & $0.04-5.00$ & $5.63 \cdot 10^{6}$ \\
\hline
\end{tabular}

found in a few samples. In food, as in other sources of exposure, lower levels of heavier PAHs are observed but decrease in their content compared to light PAHs is relatively smaller than, for example in the air. Another group of compounds often distinguished due to the provisions of EU law [4] is the sum of $4 \mathrm{PAHs}$, which include benz $(a)$ anthracene, benzo(b)fluoranthene, benzo $(a)$ pyrene and chrysene. Data in this field has shown that they represent about $60 \%$ of the content of 4 or more rings PAH in food [7]. $\operatorname{Benzo}(a)$ pyrene is distinguished among PAHs due to its significant toxicity as well as for comparison with results many previous studies. Additionally, in the case of the list of PAHs established by EC recommendation [3], models with 2 and 8 compounds were also used for risk assessment [7]. In this study PAHs were classified into groups listed in Table 2.

This study involved 52 adult respondents $(n=52)$, including 22 men and 30 women. Since no differences in PAH metabolism are observed between men and women, results were analyzed in relation to the entire study population. For obtained results, which were contents of individual PAHs in the daily diet, quantile parameters were calculated, such as 10th percentile (P10), 25th percentile (P25), median (Me), 75th percentile (P75), 90th percentile (P90), number and rate of results above the limit of quantification (LOQ). These values are presented in Table 3 and in the box plot 1. Statistical calculations for estimation of PAH levels was carried out takin into account medium bound approach [6], i.e. values below the limit of quantification (LOQ) were assigned a value of the limit of detection (LOD), while values below the limit of detection (LOD) were assigned a value of zero. For assessment of high consumer exposure value of P95 of contamination is typically used, but due to the limited number of respondents in this study, a more meaningful $P 90$ value with greater statistical certainty was used for this purpose. In the case of the presence of most chemical contaminants of food, including PAHs, normal distribution is not observed, therefore estimators such as mean and standard deviation were not used as non-representative. 
Table 2. Classification PAHs into groups used in this study

\begin{tabular}{|c|c|c|c|c|c|c|c|c|c|c|c|}
\hline PAHs & $\begin{array}{l}\text { Nap } \\
\text { Ace } \\
\text { Acy }\end{array}$ & $\begin{array}{l}\text { FLU } \\
\text { PHE } \\
\text { ANT } \\
\text { FLN } \\
\text { PYR }\end{array}$ & $\mathrm{BcFl}$ & $\mathrm{BaA}$ & CHR & $5 \mathrm{MCh}$ & $\begin{array}{l}\text { PER } \\
\text { BeP }\end{array}$ & $\begin{array}{l}\mathrm{BbF} \\
\mathrm{BaP}\end{array}$ & $\begin{array}{c}\text { BkF } \\
\text { BghiP } \\
\text { IcdP } \\
\text { DBahA }\end{array}$ & $\begin{array}{c}\text { BjF } \\
\text { DBaeP } \\
\text { DBalP } \\
\text { DBahP } \\
\text { DBaiP }\end{array}$ & CPcdP \\
\hline 22 PAHs & & + & + & + & + & + & + & + & + & + & \\
\hline Light PAHs & & + & + & + & + & + & & & & & \\
\hline Heavy PAHs & & & & & & & + & + & + & + & \\
\hline Sum of 4 PAHs & & & & + & + & & & + & & & \\
\hline PAH2 EC [7] & & & & + & + & & & & & & \\
\hline PAH4 EC [7] & & & & + & + & & & + & & & \\
\hline PAH8 EC [7] & & & & + & + & & & + & + & & \\
\hline 15 PAH EC & & & & + & + & + & & + & + & + & + \\
\hline $16 \mathrm{PAH}$ EC/JECFA & & & + & + & + & + & & + & + & + & + \\
\hline 16 US EPA & + & + & & + & + & & & + & + & & \\
\hline
\end{tabular}

Table 3. PAH content in the total diet. Table shows number of samples above the limit of quantification and quantile parameters such as: 10th percentile (P10), 25th percentile (P25), median (Me), 75th percentile (P75), 90th percentile (P90). For purpose of statistical calculations medium bound approach [6] was adopted

\begin{tabular}{|c|c|c|c|c|c|c|c|c|}
\hline \multirow{3}{*}{ PAH } & \multirow{3}{*}{$\begin{array}{l}\text { No. } \\
\text { of rings }\end{array}$} & \multicolumn{2}{|c|}{ Results above LOQ } & \multicolumn{5}{|c|}{ PAHs content in total diet } \\
\hline & & No. & Rate & P10 & $\mathrm{P} 25$ & median & P75 & P90 \\
\hline & & & $\%$ & $\mu \mathrm{g} / \mathrm{kg}$ & $\mu \mathrm{g} / \mathrm{kg}$ & $\mu \mathrm{g} / \mathrm{kg}$ & $\mu \mathrm{g} / \mathrm{kg}$ & $\mu \mathrm{g} / \mathrm{kg}$ \\
\hline FLN & 3 & 52 & 100 & 0.578 & 0.712 & 1.151 & 1.39 & 2.574 \\
\hline PHE & 3 & 52 & 100 & 1.123 & 1.217 & 1.276 & 1.654 & 2.284 \\
\hline ANT & 3 & 52 & 100 & 0.138 & 0.152 & 0.273 & 0.322 & 0.388 \\
\hline FLT & 4 & 52 & 100 & 0.704 & 0.951 & 1.087 & 1.527 & 1.663 \\
\hline PYR & 4 & 52 & 100 & 0.956 & 1.171 & 1.412 & 1.976 & 2.223 \\
\hline $\mathrm{BcFl}$ & 4 & 52 & 100 & 0.063 & 0.069 & 0.096 & 0.120 & 0.240 \\
\hline $\mathrm{BaA}$ & 4 & 52 & 100 & 0.036 & 0.047 & 0.062 & 0.110 & 0.140 \\
\hline CHR & 4 & 52 & 100 & 0.071 & 0.085 & 0.117 & 0.171 & 0.197 \\
\hline $5 \mathrm{MCh}$ & 4 & 30 & 58 & $<0.020$ & $<0.020$ & 0.027 & 0.038 & 0.046 \\
\hline PER & 5 & 43 & 83 & $<0.040$ & 0.048 & 0.059 & 0.157 & 0.387 \\
\hline $\mathrm{BbF}$ & 5 & 52 & 100 & 0.024 & 0.029 & 0.070 & 0.118 & 0.124 \\
\hline $\mathrm{BkF}$ & 5 & 52 & 100 & 0.008 & 0.010 & 0.017 & 0.031 & 0.051 \\
\hline $\mathrm{BjF}$ & 5 & 0 & 0 & $<0.120$ & $<0.120$ & $<0.120$ & $<0.120$ & $<0.120$ \\
\hline $\mathrm{BeP}$ & 5 & 52 & 100 & 0.080 & 0.084 & 0.109 & 0.150 & 0.204 \\
\hline $\mathrm{BaP}$ & 5 & 52 & 100 & 0.014 & 0.016 & 0.032 & 0.066 & 0.122 \\
\hline BghiP & 6 & 52 & 100 & 0.023 & 0.036 & 0.065 & 0.082 & 0.221 \\
\hline IcdP & 6 & 35 & 67 & $<0.020$ & $<0.020$ & 0.029 & 0.054 & 0.126 \\
\hline DBahA & 5 & 0 & 0 & $<0.040$ & $<0.040$ & $<0.040$ & $<0.040$ & $<0.040$ \\
\hline DBaeP & 6 & 0 & 0 & $<0.040$ & $<0.040$ & $<0.040$ & $<0.040$ & $<0.040$ \\
\hline DBalP & 6 & 0 & 0 & $<0.040$ & $<0.040$ & $<0.040$ & $<0.040$ & $<0.040$ \\
\hline DBahP & 6 & 0 & 0 & $<0.040$ & $<0.040$ & $<0.040$ & $<0.040$ & $<0.040$ \\
\hline DBaiP & 6 & 0 & 0 & $<0.040$ & $<0.040$ & $<0.040$ & $<0.040$ & $<0.040$ \\
\hline Light PAHs & $3-4$ & & & 4.171 & 4.890 & 6.045 & 6.89 & 9.31 \\
\hline Heavy PAHs & $5-6$ & & & 0.221 & 0.240 & 0.504 & 0.794 & 1.100 \\
\hline Sum of 4 PAHs & $4-5$ & & & 0.151 & 0.228 & 0.301 & 0.469 & 0.520 \\
\hline
\end{tabular}


For most of tested PAHs results above the limit of quantification were observed in $100 \%$ or about $100 \%$ of cases. Similarly authors of the study [23], who examining content of PAHs from the EPA list in typical diet ingredients (bread, cookies, tea, coffee, oils, chocolate, spices and fish) also found PAHs levels above the limit of quantification in all samples. A significantly lower number of results above the quantification limit was found for 5-methylchrysene. In case of 6 for indeno(1,2,3-cd)pyrene and benzo $(k)$ fluoranthene are comparable. It should be noted that in study cited above, the average values are several times higher than the median value. As there are no details regarding the composition of diets, the reason of difference may be related to the type of diet. In this study, the assumption was that participants consume a freely composed balanced diet, but with the use of various ingredients contributing PAHs to their diet.

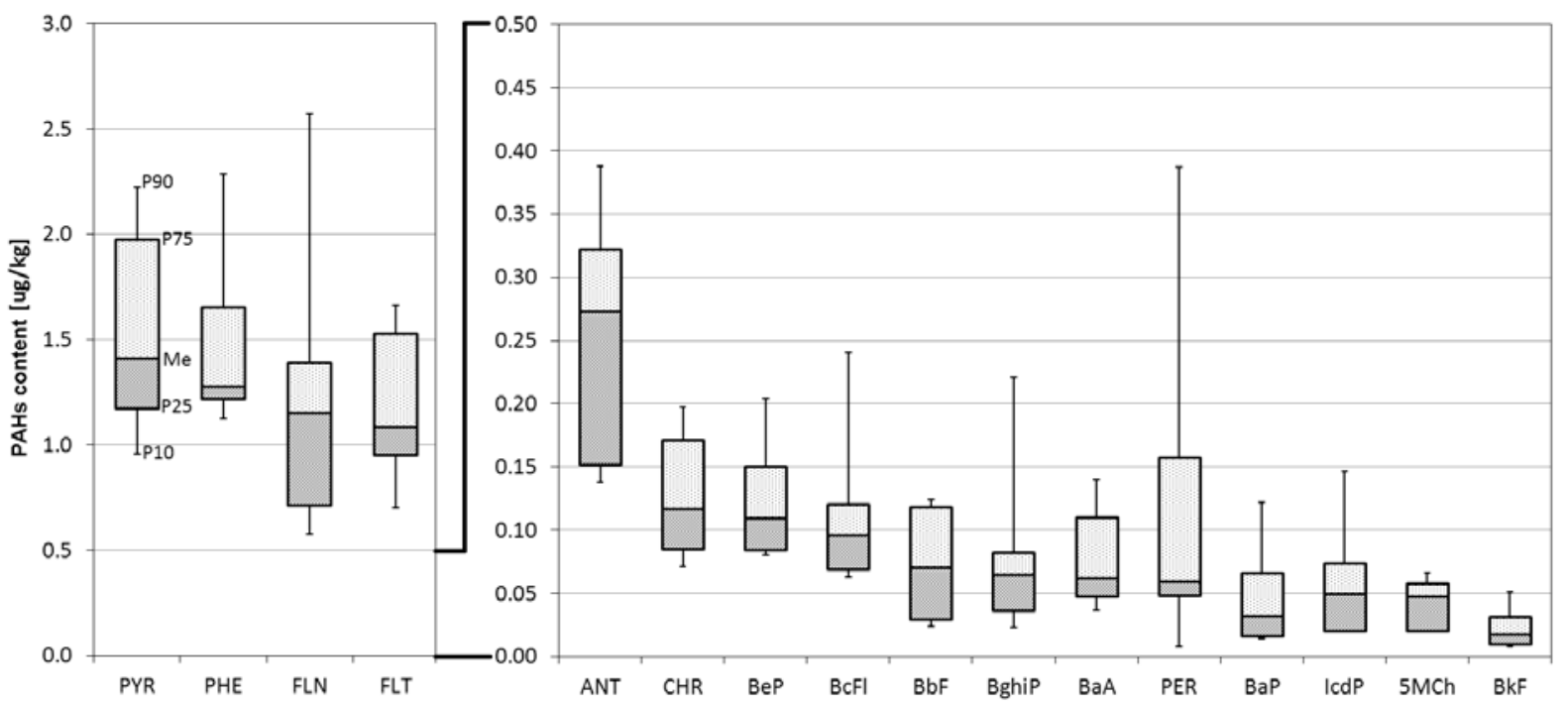

Figure 1. The prevalence of PAHs in studied diets - box diagram represents P25-median-P75 ranges, P10 and P90 values are plotted on the lines to the bars

heavier PAHs: benzo( $j)$ fluoranthene, $\operatorname{dibenzo}(a, h)$ anthracene, dibenzo $(a, e)$ pyrene, $\operatorname{dibenzo}(a, l)$ pyrene, dibenzo $(a, h)$ pyrene and dibenzo $(a, i)$ pyrene these compounds were not found in tested samples. These compounds are also rarely observed in monitoring of food samples. The highest values of median and P90 occurrence were found for pyrene, phenanthrene, fluorene and fluoranthene, respectively they were about 10-80 higher than the levels of the heavier PAHs. The lowest levels were observed for benzo $(k)$ fluoranthene, indeno $(1,2,3-c d)$ pyrene and benzo $(a)$ pyrene. In group of light PAHs the lowest levels were found for 5-methylchrysene and $\operatorname{benz}(a)$ anthracene. In case of group of heavier hydrocarbons benzo(e)pyrene and benzo(b)fluroanthene were predominant. In a comparable study by Polachowa et al. [20] the highest median levels were observed for phenanthrene $(0.858-0.861 \mathrm{ng} / \mathrm{g})$, fluoranthene $(0.191-0.192 \mathrm{ng} / \mathrm{g})$ and pyrene (0.137-0.169 ng/g). These values are significantly lower than those recorded in this work. In the case of heavier PAHs, the author [20] obtained a median in range of 0.006$0.017 \mathrm{ng} / \mathrm{g}$, excluding dibenzopyrene which were not found. Also in this case, results in this study indicates a higher contamination of the diet, ca. 2 times higher in relation to benzo $(a)$ pyrene and 3-4 times higher for benzo(b)fluoranthene and benzo(ghi)perylene, values

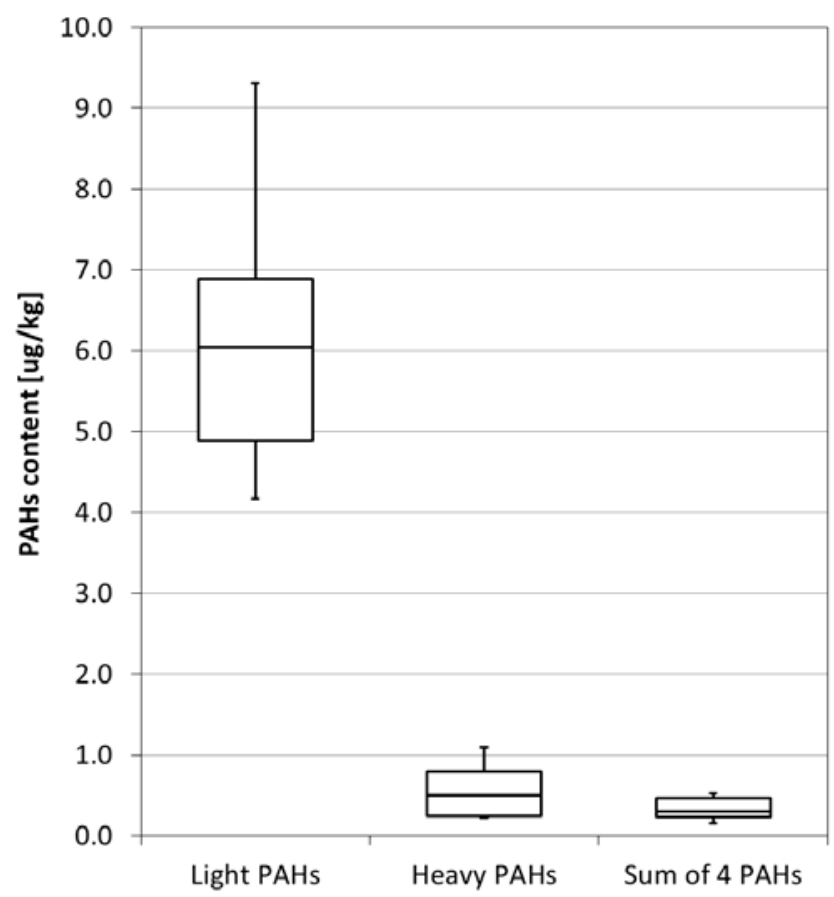

Figure 2. Occurrence of light PAHs, heavy PAHs and the sum of 4 PAHs (benz $(a)$ anthracene, benzo $(b)$ fluoranthene, benzo $(a)$ pyrene and chrysene) in the studied diets - box plot represents the $\mathrm{P} 25$-median-P75 ranges, using the lines at the bars P10 and P90 values are shown 
The results for the discussed individual PAHs and their groups are presented in the Table 3 and in Figure 2. The median and P90 levels content of light PAHs was respectively 12 and 8 times higher than the content of heavier PAHs observed in the samples.

Taking into account obtained results it is possible to estimate contribution of individual PAHs in the diet, relevant data are presented in Figure 3. In tested samples at the median level pyrene, which did not have a significant toxic effect, contributed ca. 24\% of total PAHs. In total light PAHs with a lower toxic potential constituted as much as $92 \%$ of all PAHs. EU legislation [4] with regard to food laid down requirements for benzo $(a)$ pyrene and sum of $4 \mathrm{PAHs,}$ the justification for establishing requirements for the sum of these compounds was the search for a model of food contamination marker by PAHs, which should represent a reasonably small number of compounds [5]. The level of the sum of 4 PAHs was in the range of $0.228-0.469 \mu \mathrm{g} / \mathrm{kg}$ (P25-P75), median $0.301 \mu \mathrm{g} /$ $\mathrm{kg}$, which corresponded to $58.4 \%$ of the content of all PAHs from EU list and is similar to the previous observations in the mentioned above EFSA report. A significant rate was also found for 4-rings benzo $(c)$
PAHs. Greater dispersions were observed at higher concentrations.

An important element of the research was the comparative analysis of the diets of individual participants. For this purpose, two groups of participants were distinguished, whose diets contained the highest levels of PAHs and the lowest levels of PAHs. For each group, diets from 10 participants were qualified - with the lowest and highest levels of PAHs, respectively.

Diets with higher levels of PAHs contained mainly products with a high level of fat or ingredients contributing PAHs to the diet: grilled products, smoked meat and fish products, cocoa-derived products and marine algae (chlorella). In this case higher level of PAHs can results from fat pyrolysis leads to the formation of PAHs, contamination from smoke (smoked meat) and from drying processes (cocoa beans, marine algae) or from environmental pollution (marine algae). Observations made are consistent with data on the presence of PAHs in individual foodstuffs $[20,25,8$, $14,19]$. Lower levels of PAHs were observed in diets containing lunch meat dishes, in particular fried and cooked, composite products with processed meat (e.g. pizza, baked beans), legumes (excluding green beans),
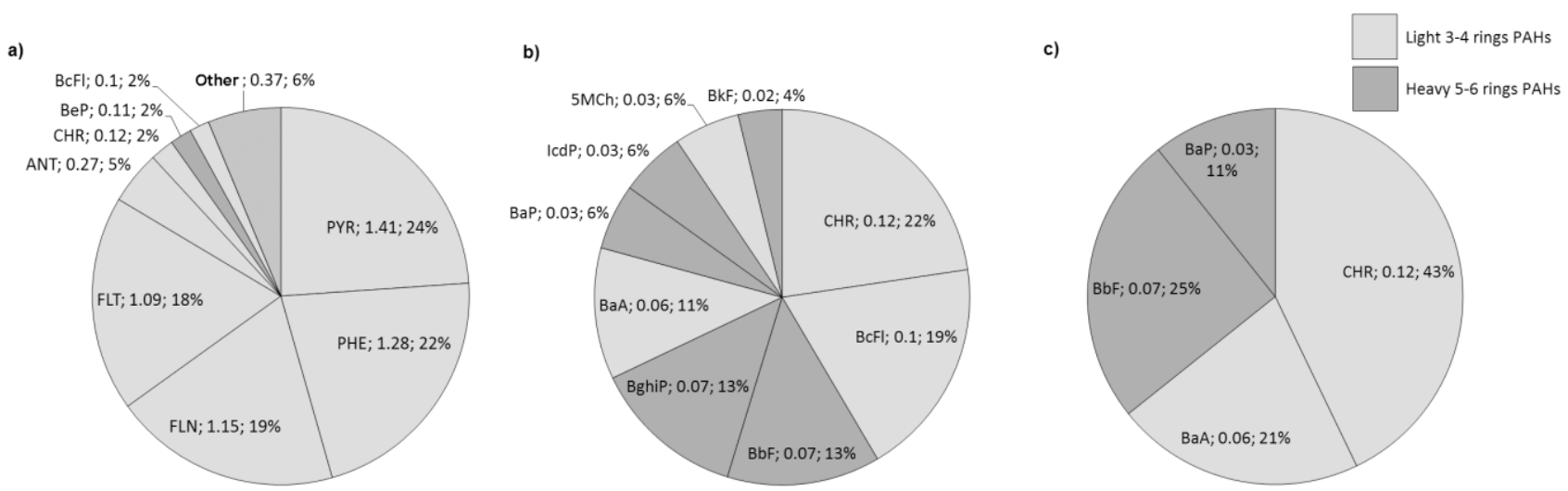

Figure 3. Contribution of individual PAHs in tested diets (level of median): a) in relation to the sum of all tested compounds, b) in relation to 15 PAHs from the EU list (cyclopenta( $c d)$ pyrene was not covered), c) in relation to the sum of 4 regulated PAHs in EU regulations [4].

fluorene (19\%), the remaining compounds constitute $22.6 \%$. Di-benzopyrenes, dibenzo $(a, h)$ anthracene and also benzo( $j$ )fluoranthene were not observed. Analyzing in detail the content of PAH sit should be stated that level of chrysene and benz $(a)$ anthracene accounted for $64 \%$ of the total of 4 compounds, similar to the study on diets tested in France. In French study content of these two compounds was 59-70\% [25].

Occurrence of light 3-4 rings PAHs is related to 5-6 rings compounds. Relevant correlation was found between the presence these PAHs groups, regression line and measurement points are shown in Figure 4. Square of the correlation coefficient was determined, which is 0.96 and indicates a significant relationship between the presence of both light and heavy

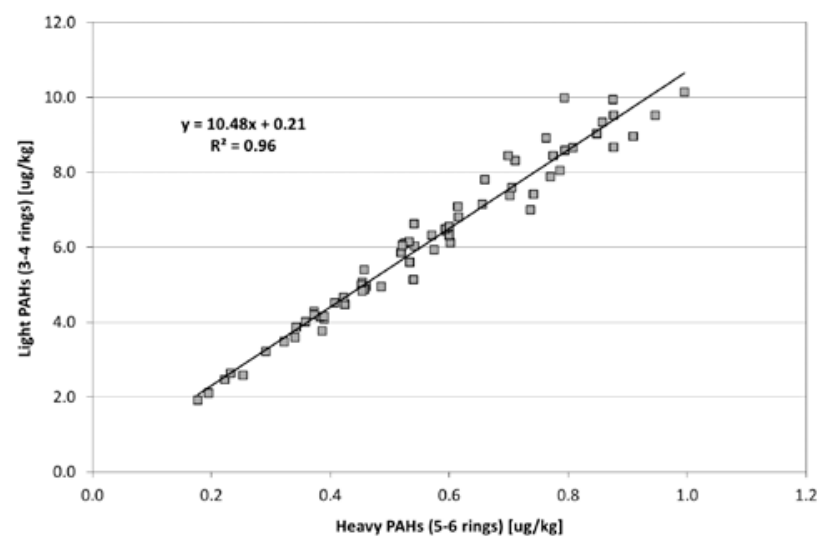

Figure 4. Correlation between presence of light PAHs and heavy PAHs in the studied diets. 
nuts and all products with a low fat content, such as vegetables, fruit, salads, as well as potatoes, pasta, rice, dairy products, bread, cookies and confectionery (excluding chocolate). It confirms the key importance of dietary composition for PAH exposure.

Another objective of this research was to determine exposure of consumers to dietary PAHs and to assess the risk to consumer health. Exposure was calculated as the product of the PAH content in diets and consumption taking into account weight of diets provided by the participants. Daily exposure values obtained in this way have been expressed in ng/person. For comparison with the toxicometric parameters and results of other studies exposures were converted $\mathrm{ng} / \mathrm{kg}$ b.w. per day taking into account corresponding body weight of participants, which were reported by respondents in study diary. Body weight of participants (adults) ranged from $48 \mathrm{~kg}$ to $105 \mathrm{~kg}$, the median was $69.7 \mathrm{~kg}$, the mean was $70.0 \mathrm{~kg}$, standard deviation was $13.8 \mathrm{~kg}$. Table 4 presents the quantile values of the exposure of studied population. There was shown exposure to all tested PAHs, light 3-4 rings PAHs, heavy PAHs 5-6 rings, sum of 4 PAHs and benzo $(a)$ pyrene. corresponding to $0.52 \mathrm{ng} / \mathrm{kg}$ b.w. per day. In EFSA scientific opinion mean value was ca. 8 times higher: $235 \mathrm{ng} /$ person, while the value expressed in relations to body weight was comparable and amounted to 3.9 $\mathrm{ng} / \mathrm{kg}$ b.w. per day. On the basis of the collected data exposure of consumers was also assessed in the higher risk group, which corresponding to the high intake of PAHs in studied diets, which is represented by P90. For light PAHs exposure was $90.6 \mathrm{ng} / \mathrm{kg}$ b.w. per day, while for heavy PAH it was $10.7 \mathrm{ng} / \mathrm{kg}$ b.w. per day. It was 8.5 times lower than the exposure to light PAH similarly to the case of average exposure. The high exposure to sum of 4 PAHs was $5.06 \mathrm{ng} / \mathrm{kg}$ b.w. per day, while for benzo $(a)$ pyrene it was $1.19 \mathrm{ng} / \mathrm{kg}$ b.w. per day. These values were also lower in comparison to the results of exposure assessment published by EFSA [7], which gives $34.5 \mathrm{ng} / \mathrm{kg}$ b.w. per day for sum of 4 PAHs and $6.5 \mathrm{ng} / \mathrm{kg}$ b.w. per day for benzo(a)pyrene. It should be noted that in both this study and EFSA assessment results for high exposure are compared, although EFSA assessment for this purpose uses intake level of P97.5 and average contamination, while in this study risk assessment is based on reliability intake and P90 level of contamination. Table 5 summarizes the results of estimated exposure and exposure values from works of other authors [7, 25, 8, 14, 12, 24, 26].

Table 4. Exposure of participants $(n=52)$ to PAHs in studied diets. Exposure to the sum of all tested PAHs, light PAHs, heavy PAHs, benzo $(a)$ pyrene and sum of 4 PAHs (benz $(a)$ anthracene, chrysene, benzo $(b)$ fluoranthene, benzo $(k)$ fluoranthene and benzo(a)pyrene)

\begin{tabular}{|c|c|c|c|c|c|c|c|c|c|c|}
\hline \multirow{3}{*}{ Quantile } & \multicolumn{10}{|c|}{ Exposure to PAHs in diets } \\
\hline & \multicolumn{2}{|c|}{ Light PAHs } & \multicolumn{2}{|c|}{ Heavy PAHs } & \multicolumn{2}{|c|}{ Total PAHs } & \multicolumn{2}{|c|}{$\operatorname{Benzo}(a)$ pyrene } & \multicolumn{2}{|c|}{ Sum of 4 PAHs } \\
\hline & $\begin{array}{c}\text { ng/ } \\
\text { person }\end{array}$ & $\begin{array}{l}\text { ng/kg } \\
\text { b.w. }\end{array}$ & $\begin{array}{c}\text { ng/ } \\
\text { person }\end{array}$ & $\begin{array}{l}\text { ng/kg } \\
\text { b.w. }\end{array}$ & $\begin{array}{c}\text { ng/ } \\
\text { person }\end{array}$ & $\begin{array}{l}\text { ng/kg } \\
\text { b.w. }\end{array}$ & $\begin{array}{c}\text { ng/ } \\
\text { person }\end{array}$ & $\begin{array}{l}\text { ng/kg } \\
\text { b.w. }\end{array}$ & $\begin{array}{c}\text { ng/ } \\
\text { person }\end{array}$ & $\begin{array}{c}\mathrm{ng} / \mathrm{kg} \\
\text { b.w. }\end{array}$ \\
\hline P10 & 2880 & 40.6 & 153 & 2.2 & 3033 & 42.8 & 9.7 & 0.14 & 104.3 & 1.47 \\
\hline $\mathrm{P} 25$ & 3376 & 47.6 & 166 & 2.3 & 3542 & 50.0 & 11.0 & 0.16 & 157.4 & 2.22 \\
\hline Median & 4173 & 58.9 & 348 & 4.9 & 4521 & 63.8 & 22.1 & 0.31 & 207.8 & 2.96 \\
\hline P75 & 4757 & 67.1 & 548 & 7.7 & 5305 & 74.8 & 45.5 & 0.64 & 323.8 & 4.57 \\
\hline P90 & 6427 & 90.6 & 760 & 10.7 & 7187 & 101.4 & 84.2 & 1.19 & 359.0 & 5.06 \\
\hline Mean & 4237 & 59.8 & 390 & 5.5 & 4627 & 65.3 & 36.7 & 0.52 & 233.4 & 3.29 \\
\hline RSD & $32.9 \%$ & & $29.7 \%$ & & $33.8 \%$ & & $32.0 \%$ & & $34.1 \%$ & \\
\hline
\end{tabular}

In most cases (excluding benzo(a)pyrene) the median exposure was close to the mean. Mean exposure to heavy PAHs was $5.5 \mathrm{ng} / \mathrm{kg}$ b.w. per day, which was 10.9 times lower than exposure to light PAHs. Exposure estimated for sum of 4 PAHs was on average $3.29 \mathrm{ng} / \mathrm{kg}$ b.w. per day, which corresponds to exposure $233.4 \mathrm{ng} /$ person per day. Compared to EFSA risk assessment [7] daily exposure to sum of 4 PAHs was estimated at $1729 \mathrm{ng} /$ day, which corresponding to $28.8 \mathrm{ng} / \mathrm{kg}$ b.w. per day (EFSA's opinion based on a body weight of $60 \mathrm{~kg}$ ) and it was significantly higher than estimated in this study. For benzo(a)pyrene the mean exposure was $36.7 \mathrm{ng} /$ person per day, which
Calculated exposure shows even 80-fold differences between certain estimates (compare [25] and [26]). These differences result primarily from the adopted methodologies of exposure estimation. Another important element is also the handling of results below the quantification limit, in this paper the medium bound approach discussed earlier was adopted. Other approaches are often used to increase (upper bound) or decrease (lower bound) mean values and other estimators. There are also different approaches to methods of collecting diets or determining its contamination based on the contribution of individual contaminated ingredients. 
Table 5. Comparison of the estimated exposure in this study and studies of other authors

\begin{tabular}{|c|c|c|c|c|}
\hline Study & Scope of PAHs & Exposure type & Exposure & Exposure unit \\
\hline \multirow{10}{*}{ this study } & \multirow{2}{*}{$22 \mathrm{PAHs}^{(\mathrm{a})}$} & average (Me of contamination) & 63.8 & ng/kg b.w./day \\
\hline & & high (P90 of contamination) & 101.4 & ng/kg b.w./day \\
\hline & \multirow{2}{*}{ light PAHs ${ }^{(b)}$} & average (Me of contamination) & 58.9 & ng/kg b.w./day \\
\hline & & high (P90 of contamination) & 90.6 & ng/kg b.w./day \\
\hline & \multirow{2}{*}{ heavy PAHs ${ }^{(\mathrm{c})}$} & average (Me of contamination) & 4.9 & ng/kg b.w./day \\
\hline & & high (P90 of contamination) & 10.7 & ng/kg b.w./day \\
\hline & \multirow{2}{*}{ Sum of 4 PAHs $^{(\mathrm{d})}$} & average (Me of contamination) & 2.96 & ng/kg b.w./day \\
\hline & & high (P90 of contamination) & 5.06 & ng/kg b.w./day \\
\hline & \multirow{2}{*}{$\mathrm{BaP}$} & average (Me of contamination) & 0.31 & ng/kg b.w./day \\
\hline & & high (P90 of contamination) & 1.19 & ng/kg b.w./day \\
\hline \multirow{8}{*}{ EFSA, 2008 [7] } & \multirow{2}{*}{$\mathrm{PAH}^{(\mathrm{e})}$} & $\begin{array}{l}\text { average (mean of contamination, Me of } \\
\text { consumption) }\end{array}$ & 28.8 & ng/kg b.w./day \\
\hline & & $\begin{array}{l}\text { average (mean of contamination, P97,5 of } \\
\text { consumption certain products) }\end{array}$ & 51.3 & ng/kg b.w./day \\
\hline & \multirow{2}{*}{$\begin{array}{c}\text { PAH } 4^{(\mathrm{d})}= \\
\text { Sum of } 4 \text { PAHs }\end{array}$} & $\begin{array}{l}\text { average (mean of contamination, } \mathrm{Me} \text { of } \\
\text { consumption) }\end{array}$ & 19.5 & ng/kg b.w./day \\
\hline & & $\begin{array}{l}\text { average (mean of contamination, P97,5 of } \\
\text { consumption certain products) }\end{array}$ & 34.5 & ng/kg b.w./day \\
\hline & \multirow{2}{*}{$\mathrm{PAH} 2^{(\mathrm{f})}$} & $\begin{array}{l}\text { average (mean of contamination, Me of } \\
\text { consumption) }\end{array}$ & 10.7 & ng/kg b.w./day \\
\hline & & $\begin{array}{l}\text { average (mean of contamination, P97,5 of } \\
\text { consumption certain products) }\end{array}$ & 18.0 & ng/kg b.w./day \\
\hline & \multirow{2}{*}{$\mathrm{BaP}$} & $\begin{array}{c}\text { average (mean of contamination, Me of } \\
\text { consumption) }\end{array}$ & 3.9 & ng/kg b.w./day \\
\hline & & $\begin{array}{l}\text { average (mean of contamination, P97,5 of } \\
\text { consumption certain products) }\end{array}$ & 6.5 & ng/kg b.w./day \\
\hline $\begin{array}{c}\text { Netherland TDS, } \\
1998[24]\end{array}$ & $15 \mathrm{PAH}^{(\mathrm{g})}$ & average for individual PAHs & $1.1-22.5$ & $\mu \mathrm{g} /$ person/day \\
\hline \multirow{6}{*}{$\begin{array}{l}\text { French TDS, } 2013 \\
\text { [25] }\end{array}$} & \multirow{2}{*}{ PAH $8^{(\mathrm{e})}$} & average & 2.281 & ng/kg b.w./day \\
\hline & & high (P95) & 4.454 & ng/kg b.w./day \\
\hline & \multirow{2}{*}{$\begin{array}{c}\text { PAH4 } 4^{(\mathrm{d})}= \\
\text { Sum of } 4 \text { PAHs }\end{array}$} & average & 1.478 & ng/kg b.w./day \\
\hline & & high (P95) & 2.998 & ng/kg b.w./day \\
\hline & $\mathrm{BaP}$ & average & 0.191 & ng/kg b.w./day \\
\hline & & high (P95) & 0.350 & ng/kg b.w./day \\
\hline $\begin{array}{c}\text { Catalonian TDS, } \\
2012[14]\end{array}$ & $16 \mathrm{EPA}^{(\mathrm{h})}$ & average & 59.2 & $\mu \mathrm{g} /$ person/day \\
\hline $\begin{array}{c}\text { Catalonian TDS, } \\
2003[8]\end{array}$ & $16 \mathrm{EPA}^{(\mathrm{h})}$ & average & 6.72 & $\mu \mathrm{g} /$ person/day \\
\hline \multirow{2}{*}{$\begin{array}{c}\text { Italian TDS, } 1994 \\
{[12]} \\
\end{array}$} & $16 \mathrm{EPA}^{(\mathrm{h})}$ & average & 3.0 & $\mu \mathrm{g} /$ person/day \\
\hline & carcinogenic $\mathrm{PAH}^{(\mathrm{i})}$ & average & 1.4 & $\mu \mathrm{g} /$ person/day \\
\hline \multirow{3}{*}{ Dutch, 1990 [26] } & $16 \mathrm{EPA}^{(\mathrm{h})}$ & low & 5 & $\mu \mathrm{g} /$ person/day \\
\hline & $16 \mathrm{EPA}^{(\mathrm{h})}$ & high & 17 & $\mu \mathrm{g} /$ person/day \\
\hline & carcinogenic $\mathrm{PAH}^{(\mathrm{i})}$ & average & 11 & $\mu \mathrm{g} /$ person/day \\
\hline
\end{tabular}

TDS - total diet study, Me - median, (a) FLN, PHE, ANT, FLT, PYR, BcFl, BaA, CHR, 5MCh, PER, BeP, BbF, BaP, BkF, BghiP, IcdP, DBahA, BjF, DBaeP, DBalP, DBahP, DBaiP; (b) FLN, PHE, ANT, FLT, PYR, BcFl, BaA, CHR, 5MCh; (c) PER, BeP, BbF, BaP, BkF, BghiP, IcdP, DBahA, BjF, DBaeP, DBalP, DBahP, DBaiP; (d) BaA, CHR, BbF, BaP; (e) BaA, CHR, BbF, BaP, BkF, BghiP, IcdP, DBahA; (f) BaA, CHR; (g) BaA, CHR, 5MCh, BbF, BaP, BkF, BghiP, IcdP, DBahA, BjF, DBaeP, DBalP, DBahP, DBaiP, CPcdP; (h) NAP, ACE, ACY, FLN, PHE, ANT, FLT, PYR, BaA, CHR, BbF, BaP, BkF, BghiP, IcdP, DBahA; (i) BaA, BbF, BaP, BkF, BghiP, IcdP, DBahA. 
Undoubtedly total diet study (in this work, also in $[8,12,14,25]$,$) is characterized by less uncertainty$ than the attempt to estimate contamination based on single diet components [7, 24]. The results obtained in this study are comparable or slightly higher than those presented in $[7,8,12,26]$. However, they are much higher than in the study [25] concerning French diets and are significantly lower than Spanish study [14], which was performed by the same team as previous study described by [8]. Differences may also arise from a varied diet. Tested national diets are characterized by higher consumption of smoked products and general meat products in contrast to lower consumption of seafood.

In this work risk assessment was performed on the basis of margins of exposure (MoE), which were calculated for sum of 4 PAHs and for benzo $(a)$ pyrene. In opinion of EFSA [7], based on the work of Culp et al. [2] toxicometric parameters were determined, such as $\mathrm{BMDL}_{10}$ for benzo $(a)$ pyrene for the genotoxic carcinogenic effect observed in rats which is $0.07 \mathrm{mg} /$ $\mathrm{kg}$ b.w. and for the total of 4 PAHs which is $0.34 \mathrm{mg} /$ $\mathrm{kg}$ b.w. Margin of exposure is calculated by division of critical toxicometric parameter (dose-response type) and consumer exposure. Indicated value of MoE informs how much less consumer is exposed in relation to dose causing toxic effect with certain probability. Calculated margins of exposure for consumers participating in study in comparison to results of EFSA assessment are presented in Table 6.

It is assumed that risk to consumer health not to be significant for genotoxic carcinogens when $\mathrm{MoE}$ value is greater than 10,000 and sometimes even greater than 25,000 in case of conservative approach. For purposes of this risk assessment $\mathrm{MoE}$ value of 10,000 has been taken as critical. Calculated margins of exposure in case of benzo(a)pyrene and in case of 4 PAHs based on results obtained of this study are much higher than results presented by EFSA [7].
Also for benzo $(a)$ pyrene and 4 PAHs in both exposure scenarios (average or high exposure) critical value, as well as conservative value $(25,000)$ is not exceeded.

\section{CONCLUSIONS}

The studied diets were a source of exposure consumers to PAHs. Higher levels have been reported for the light, less toxic PAHs compared to the more toxic 5-6 ring PAHs. Greater exposure of consumers to tested compounds is associated with the consumption of products with a high fat content including fried, grilled and smoked meat, as well as smoked fish. Low exposure was resulted from the high proportion of fruit, vegetables and cereal-based products in diets. Exposure of surveyed consumers was comparable to exposure estimated by EFSA for EU consumers. Risk assessment shows that margins of exposure (MoE) are not exceeded for benzo $(a)$ pyrene and 4 PAHs in case of both medium and high exposure scenarios.

\section{Conflict of interest}

The authors declare no conflict of interest.

\section{Acknowledgements}

This work has been financed by the National Science Center, in the frame of research project No. 2011/01/N/NZ7/06227 entitled 'Human health exposure assessment based on the analysis of exposure biomarkers related to the intake of carcinogenic polycyclic aromatic hydrocarbons (PAHs) in the diet'.

\section{REFERENCES}

1. Aquilina, N.J., Delgado-Saborit, J.M., Meddings, C., Baker, S., Harrison, R.M., Jacob III, P., Wilson, M., $Y u, L .$, Duan, M. \& Benowitz, N.L.: Environmental

Table 6. Comparison of risk assessment for consumer health based on the exposure determined in this study and results of EFSA assessment

\begin{tabular}{|c|c|c|c|c|c|}
\hline Study & PAHs & $\begin{array}{c}\text { Exposure } \\
\text { scenario }\end{array}$ & $\begin{array}{c}\text { Exposure } \\
\text { [ng/kg b.w.] }\end{array}$ & $\begin{array}{c}\text { BMDL }_{10} \\
{[\mathrm{mg} / \mathrm{kg} \mathrm{b.w.]}}\end{array}$ & MoE \\
\hline \multirow{4}{*}{ this study } & \multirow{2}{*}{$\mathrm{BaP}$} & average & 0.31 & 0.07 & $>25,000$ \\
\hline & & high & 1.19 & 0.07 & $>25,000$ \\
\hline & \multirow{2}{*}{ Sum of 4 PAHs } & average & 2.96 & 0.34 & $>25,000$ \\
\hline & & high & 5.06 & 0.34 & $>25,000$ \\
\hline \multirow{4}{*}{ EFSA, 2008 [7] } & \multirow{2}{*}{$\mathrm{BaP}$} & average & 3.9 & 0.07 & 17,950 \\
\hline & & high & 6.5 & 0.07 & 10,750 \\
\hline & \multirow{2}{*}{ Sum of 4 PAHs } & average & 19.5 & 0.34 & 17,450 \\
\hline & & high & 34.5 & 0.34 & 9,850 \\
\hline
\end{tabular}

$\mathrm{BMDL}_{10}$ - benchmark dose low level limit at $10 \%$, MoE - margin of exposure, 4 PAHs: benz $(a)$ anthracene, benzo $(b)$ fluoranthene, benzo(a)pyrene, chrysene 
and biological monitoring of exposures to PAHs and ETS in the general population. Environment International 2010;36(7):763-771.

2. Culp, S.J., Gaylor, D.W., Sheldon, W.G., Goldstein, L.S. and Beland, F.A.: A comparison of the tumours induced by coal tar and benzo $[a]$ pyrene in a 2-year bioassay. Carcinogenesis 1998;19:117124.

3. EC. Commission Recommendation of 4 February 2005 on the further investigation into the levels of polycyclic aromatic hydrocarbons in certain foods. Off J EU L 34, 8.2.2005, p. 43-45.

4. EC. Commission Regulation (EC) No 1881/2006 of 19 December 2006 setting maximum levels for certain contaminants in foodstuffs. Off J UE L 364, 20.12.2006, p. 5-24, consolidated version 14/10/2020.

5. EFSA. A Report from the Unit of Data Collection and Exposure on a Request from the European Commission: Findings of the EFSA Data Collection on Polycyclic Aromatic Hydrocarbons in Food. EFSA, 2008.

6. EFSA. Management of left-censored data in dietary exposure assessment of chemical substances. EFSA Journal 2010; 8(3):96 pp.

7. EFSA. Scientific Opinion of the Panel on Contaminants in the Food Chain on a request from the European Commission on Polycyclic Aromatic Hydrocarbons in Food. The EFSA Journal 2008;724:1-114.

8. Falcó G., Domingo J.L., Llobet J.M., Teixidó A., Casas C., Müller L.: Polycyclic Aromatic Hydrocarbons in Foods: Human Exposure through the Diet in Catalonia, Spain. Journal of Food Protection 2003;66(12):2325-2331.

9. Gerald G. Moy G.G., Vannoort R.W.: Total Diet Studies, Springer, New York 2013.

10. IARC Monographs on the Evaluation of Carcinogenic Risks to Humans. Volume 92: Some Non-heterocyclic Polycyclic Aromatic Hydrocarbons and Some Related Exposures. World Health Organization, International Agency for Research on Cancer. France 2010.

11. JECFA. A Sixty-fourth report of the Joint FAO/WHO Expert Committee on Food Additives: Chapter 3.6 Polycyclic aromatic hydrocarbons. In: Evaluation of Certain Food Contaminants. Geneve 2006.

12. Lodovici M., Dolara P., Casalini C., Ciappellano S., Testolin G.: Polycyclic aromatic hydrocarbons contamination in the Italian diet. Food Add Cont 1995;12(5):703-713.

13. Marczynski, B., Raulf-Heimsoth, M., Käfferlein, H.U., Förster, K., Spickenheuer, A., Pesch, B., Breuer, D., Angerer, J., Welge, P., Bramer, R., Hahn, J.-U., Mensing, T. \& Brüning, T.: Risk assessment of workers exposed to fumes of bitumen: genotoxic effects and urinary metabolites of naphthalene, phenanthrene, and pyrene. Abstracts of the 44th Congress of the European Societies of Toxicology. Toxicology Letters 2007;172 (Supplement 1), S172-S173.

14. Martorell I., Nieto A., Nadal M., Perelló G., Marcé R.M., Domingo J.L.: Human exposure to polycyclic aromatic hydrocarbons (PAHs) using data from a duplicate diet study in Catalonia, Spain. Food
Chem Toxicol 2012;50(11):4103-8, doi: 10.1016/j. fct.2012.08.011.

15. Mensing T., Marczynski B., Engelhardt B., Wilhelm M., Preuss R., Kappler M., Angerer J., Käfferlein H.U., Scherenberg M., Seidel A., Brüning T.: DNA adduct formation of benzo[ $a]$ pyrene in white blood cells of workers exposed to polycyclic aromatic hydrocarbons. Int. J. Hyg. Environ.-Health 2005;208:173-178.

16. Munoz B., Albores A.: Chapter 6. DNA Damage Caused by Polycyclic Aromatic Hydrocarbons: Mechanisms and Markers. In: Selected Topics in DNA Repair (pp.125-144), InTech, USA 2011.

17. Nisbet I.C., LaGoy P.K.: Toxic equivalency factors (TEFs) for polycyclic aromatic hydrocarbons (PAHs). Regul Toxicol Pharmacol 1992;16(3):290-300.

18. Pavanello S., Pulliero A., Saia B.O., Clonfero E.: Determinants of anti-benzo $[a]$ pyrene diol epoxideDNA adduct formation in lymphomonocytes of the general population. Mutation Research 2006;611:54-63.

19. Phillips D.H.: Polycyclic aromatic hydrocarbons in the diet. Mutation Research 1999, 443, 139-147.

20. Polachova A. Gramblicka T., Parizeka O., Sram R.J., Stupaka M, Hajslova J., Pulkrabova J.: Estimation of human exposure to polycyclic aromatic hydrocarbons (PAHs) based on the dietary and outdoor atmospheric monitoring in the Czech Republic. Environmental Research 2020;182:108977, doi: 10.1016/j. envres.2019.108977.

21. Preuss, R., Roßbach, B., Wilhelm, M., Brüning, T. \& Angerer, $J$.: External and internal exposure to polycyclic aromatic hydrocarbons (PAH) among workers in the production of fire-proof materials Proposal of a biological monitoring guidance value. International Journal of Hygiene and Environmental Health, 2006;209(6):575-580.

22. SCF. Scientific Committee on Food: Opinion of the Scientific Committee on Food on the risks to human health of Polycyclic Aromatic Hydrocarbons in food (SCF/CS/CNTM/PAH/29 Final), Brussels 2002.

23. Singh L., Agarwal T.: PAHs in Indian diet: Assessing a cancer risk. Chemosphere, 2018;202:366-376, doi: 10.1016/j.chemosphere.2018.03.100.

24. Vaessen H.A.M.G., Jekel A.A., Wilbers A.A.M.M.: Dietary intake of polycyclic aromatic hydrocarbons. Toxicological \& Environmental Chemistry 1998;16:281-294.

25. Veyrand B. Sirot V., Durand S., Pollono C., Marchand P., Dervilly-Pinel G., Tard A., Leblanc J-C., Le Bizec $B$.: Human dietary exposure to polycyclic aromatic hydrocarbons: Results of the second French Total Diet Study. Environment International 2013;54:11-17, doi: 10.1016/j.envint.2012.12.011

26. Vos R.H., Dokkum W., Schouten A., Jong-Berkhout P.: Polycyclic aromatic hydrocarbons in Dutch total diet samples (1984-1986). Food Chem Tox 1990;28(4):263268, doi: 10.1016/0278-6915(90)90038-O. 
27. WHO. Chapter 5.9 PAHs Air Quality Guidelines. In: WHO air quality guidelines for Europe, 2nd edition, 2000.

28. WHO. Polynuclear aromatic hydrocarbons in Drinking-water. Background document for preparation of WHO Guidelines for Drinking-water quality. Geneva, World Health Organization (WHO/ SDE/WSH/03.04/59) 2003.
29. Zelinkova Z, Wenzl T.: The Occurrence of 16 EPA PAHs in Food - A Review. Polycyclic Aromatic Compounds, 2015;35:2-4, 248-284.

Received: 20.03.2021

Accepted: 30.06.2021 